\title{
Effect of management system and dietary yeast autolysate on the performance, slaughter and carcass characteristics of partridges (Alectoris chukar)
}

\author{
M. Bolacali ${ }^{1 \#}$, M. Küçük ${ }^{2}$, T. Tufan ${ }^{3} \&$ L. Aslan ${ }^{4}$ \\ ${ }^{1}$ Siirt University, Faculty of Veterinary Medicine, Department of Animal Breeding and Husbandry, Siirt, Turkey \\ ${ }^{2}$ Yuzuncu Yil University, Faculty of Veterinary Medicine, Department of Animal Breeding and Husbandry, Van, Turkey \\ ${ }^{3}$ Siirt University, Veterinary Medicine Faculty, Department of Animal Nutrition and Nutritional Disease, Siirt, Turkey \\ ${ }^{4}$ Yuzuncu Yil University, Wild Animals Conservation and Rehabilitation Application and Research Center, Van, Turkey
}

(Received 3 November 2017; Accepted 21 December 2017; First published online 27 December 2017)

Copyright resides with the authors in terms of the Creative Commons Attribution 4.0 South African Licence.

See: http://creativecommons.org/licenses/by/4.0/za

Condition of use: The user may copy, distribute, transmit and adapt the work, but must recognise the authors and the South African Journal of Animal Science.

\begin{abstract}
This study was conducted to determine the effects of management system (a floor housing (FH) versus a free-range housing (FRH) system) and dietary yeast autolysate (Saccharomyces cerevisiae) (1\% versus $2 \%$ dietary supplement) on the performance, slaughter and carcass characteristics of partridges (Alectoris chukar). A total of 480 (240 for each management system) one-day-old male partridge chicks were randomly allocated to a control group and the two dietary groups per production system, each containing 80 chicks. Each dietary group was then divided into five replicate groups of 16 chicks. The study lasted 112 days. In terms of growth performance, partridges reared under FRH management system had a lower average daily live weight gain (ADG), a significantly higher feed intake (FI), and feed conversion ratio (FCR) compared to the control group. However, partridges fed diets with yeast autolysate had a significantly higher ADG, lower FI, and an improved FCR compared to the control group overall. The gizzard, leg, and wing percentages of the partridges reared in the $\mathrm{FRH}$ system were found to be significantly higher than those of partridges reared in the $\mathrm{FH}$ system, while the breast and abdominal fat percentages were found to be lower. Dietary supplementation with yeast autolysate significantly increased the cold carcass yield and breast percentage when compared to the control group, while wing and abdominal fat percentages were decreased. In general, best performance was observed in the dietary supplementation group of $1 \%$ yeast autolysate in terms of growth and carcass parameters. When considering the fact that partridges are gamebirds, that housing poultry in cage production systems has been prohibited in recent years and that there are positive effects associated with using yeast autolysate as a prebiotic, it is recommended that a free-range production system should be used for partridge breeding, with the addition of $1 \%$ yeast autolysate to the diet of the birds.
\end{abstract}

Keywords: Carcass attributes, gamebird, growth, housing system

\#Corresponding author: bolacali@gmail.com

\section{Introduction}

Partridges are found worldwide and in a variety of habitats, including forests, deserts and meadows. There are about 94 species (Alectoris chukar, Alectoris graeca, Perdix perdix L., etc.) of partridges in the world domesticated and wild, with 5 types of partridges known in Turkey. Among the species of partridges in the world, the red-legged partridge, Alectoris chukar, is the best adapted for wildlife and commercial production. This partridge species is also common in Turkey (Yilmaz \& Tepeli, 2009; Wnuk et al., 2014).

Farmed gamebirds are wild bird species that are now being raised domestically for different purposes. The partridge is one of the easiest gamebirds to farm. They are raised primarily for release for hunting; secondly, for meat production and breeding (free-range or floor housing, etc.); thirdly, for release to increase the natural population and to protect biodiversity; and fourthly, for recreational purposes (Yolcu et al., 2013; Wnuk et al., 2014; Yamak et al., 2016).

Many different management systems are used in poultry production. In the majority of cases, the cage production system is applied in order to reduce costs by making use of continuous expenses and to increase the yield per poultry house via intensive breeding. However, it is established that the cage system leads to 
fear and stress, is a cause of welfare issues and limits many important behaviours in terms of physical and mental health (Yenilmez \& Uruk, 2016; Simsek et al., 2017). Although partridges have been reared domestically in floor housing (FH) systems for many years, they are classified as "wild birds" when compared to other poultry species. Consideration of the management or housing system is important for individuals who consume gamebird meat, since the meat of gamebirds is more of a delicacy than that of domesticated poultry and it is more light as a meal than that of wild birds. Gamebirds reared in a free-range housing (FRH) system have more freedom of movement and, for this reason, have lower body fat percentages when compared to domesticated birds and those reared in cage production systems. In addition, providing poultry with free areas under managed conditions is an efficient method to obtain a flavour that is similar to the meat of gamebirds reared in the wild. The use of $\mathrm{FRH}$ in production systems has become widespread in the light of directives of the European Union, and due to consideration of the positive effects of the FRH system and the negative effects of the FH system on production (Yamak et al., 2016; Yenilmez \& Uruk, 2016; Simsek et al., 2017). For instance, Yamak et al. (2016) found that partridges that were reared in a barn had higher carcass parameters (except for wing percentage) than those reared in free-range systems.

Since the use of antibiotics in poultry diets to increase performance was banned in 2006 in European Union countries, several studies have been conducted into the use of natural additives as alternatives to antibiotics (Castanon, 2007). Therefore, numerous studies conducted in recent years have examined the use of various yeasts and yeast-products in poultry diets, including inactive dry yeast, yeast culture, yeast autolysate, yeast cell walls, and live yeast, as alternative natural growth and performance enhancers (Bonos et al., 2010; Aydin \& Aydin, 2012; Mousa et al., 2014). In particular, yeast autolysate, containing yeast cell walls obtained from inactive yeast, is a prebiotic and a good source of nutrients, containing $\beta$-glucans, mannan-oligosaccharides (MOS) that shift the gastrointestinal microflora balance towards beneficial organisms, proteins, lipids, and chitin (Patterson \& Burkholder, 2003; Nikpiran et al., 2013). Moreover, yeast autolysate has performance-enhancing effects when used as a feed supplement for poultry (Bolacali \& Irak, 2017). Khaksar et al. (2014) conducted a study, and found that using prebiotics in partridge diets reduced the feed intake and back-neck percentage and increased the breast and intestine percentages.

The production of partridge has become widespread in recent years. Determining suitable breeding systems for partridges and adding dietary prebiotics are important in terms of reducing economic losses during the growth period and ensuring higher performance. However, studies conducted into various breeding systems on the use of dietary supplementation with yeast autolysate as an alternative to antibiotics and the effects of this additive on performance in partridges, are lacking. The aim of this study was therefore to determine the effects of dietary yeast autolysate and different management systems on performance, slaughter, and carcass characteristics in partridges.

\section{Materials and Methods}

This experiment was conducted at the Yuzuncu Yil University Wild Animals Conservation and Rehabilitation Application and Research Center. All animal-use protocols were performed in accordance with the guide of Application and Research Center and Directive 2010/63/EU of the European Parliament and Council of 22 September 2010, on the protection of animals used for scientific purposes.

A total of 480 (240 in $\mathrm{FH}$ and 240 in $\mathrm{FRH}$-system) one-day-old male chicks (Alectoris chukar) were randomly allocated to a control group and two experimental dietary groups per production system, each containing 80 chicks. Each dietary group was then divided into five replicate groups of 16 chicks. Cetin and Kirikci (2000) reported that the optimal stock density for partridge raising was $600 \mathrm{~cm}^{2} /$ partridge. The chicks of all the replicate groups for the floor housing $(\mathrm{FH})$ system were housed in cages measuring $0.46 \times 2.06 \times$ $0.30 \mathrm{~m}$ in width, length and height, respectively $\left(592 \mathrm{~cm}^{2} /\right.$ chick). The chicks of all the replicate groups for the free-range housing $(\mathrm{FRH})$ system were housed in cages measuring $2.0 \times 2.0 \times 3.0 \mathrm{~m}$ in width, length and height, respectively $\left(2500 \mathrm{~cm}^{2} /\right.$ chick). At 56 days of age, 24-hour access was given to the chicks in the FRH system to outdoor pens measuring $6.0 \times 2.0 \times 3.0 \mathrm{~m}$, through a door measuring $0.60 \times 0.60 \mathrm{~m}(7,500$ $\mathrm{cm}^{2} /$ chick). A 24-h light regime was applied at $1-3$ days of age, which was reduced gradually to $14 \mathrm{~h}$ at 4 56 days of age; this light regime was continued until slaughter.

The yeast autolysate (InteWall, S. cerevisiae, NCYC R 625, Integro Food and Feed Manufacturing Company, İstanbul, Turkey) which was used as a prebiotic in this study, consists of $92 \%$ dry matter, $40 \%$ crude protein, and $32 \%$ MOS and $\beta$-glucans. The study lasted 112 days. The partridges were initially fed a prepared starter diet (weeks 1 - 8), followed by a grower diet (weeks 9 - 16) (Table1). The raw nutrient contents of the mixed feedstock used in the study were determined in accordance with AOAC (2000) in the Laboratory for Animal Nutrition and Nutritional Diseases at the Faculty of Veterinary Medicine of Siirt University. The basal diets were supplemented with yeast autolysate instead of wheat bran, at levels of $0 \%$ (control), $1 \%$ (trial 1\%), and $2 \%$ (trial $2 \%$ ). The diets were offered ad libitum in mashed form and water was available at all times during the experimental period. 
Table 1 Ingredient composition and analyzed content of nutrients of the diets used in the trial (starter diet: days 1 - 56; grower diet: days $57-112$ )

\begin{tabular}{|c|c|c|c|c|c|}
\hline Ingredients (\%) & $\begin{array}{l}\text { Starter } \\
\text { Diet }\end{array}$ & $\begin{array}{l}\text { Grower } \\
\text { Diet }\end{array}$ & $\begin{array}{l}\text { Nutritional content, DM } \\
\text { basis }(\%)\end{array}$ & $\begin{array}{c}\text { Starter } \\
\text { Diet }\end{array}$ & $\begin{array}{c}\text { Grower } \\
\text { Diet }\end{array}$ \\
\hline Yellow corn & 47.00 & 45.00 & Dry matter & 90.10 & 89.90 \\
\hline Barley & 4.95 & 15.40 & Metabolic energy & & \\
\hline Wheat bran & 2.00 & 7.00 & $\mathrm{kcal} / \mathrm{kg}$ & 2918 & 2732 \\
\hline Vegetable oil & 1.90 & 0.50 & $\mathrm{MJ} / \mathrm{kg}$ & 12.21 & 11.42 \\
\hline Soybean meal (48\% CP) & 37.50 & 28.00 & Crude protein & 25.05 & 20.10 \\
\hline Fish meal $(64 \% \mathrm{CP})$ & 3.50 & - & Crude fat & 3.70 & 2.39 \\
\hline DCP & 1.40 & 2.00 & Crude fibre & 3.00 & 3.68 \\
\hline Limestone & 1.10 & 1.30 & Crude ash & 6.55 & 6.74 \\
\hline Salt & 0.30 & 0.30 & Calcium & 1.08 & 1.10 \\
\hline Vit. min. prem. ${ }^{*}$ & 0.25 & 0.25 & $\mathrm{P}$ & 0.54 & 0.51 \\
\hline D-L Methionine & 0.10 & 0.10 & $\mathrm{Na}$ & 0.18 & 0.15 \\
\hline \multirow[t]{5}{*}{ L-Lysine } & - & 0.15 & $\mathrm{Cl}$ & 0.25 & 022 \\
\hline & & & Meth. + Cysteine & 0.96 & 0.78 \\
\hline & & & Lysine & 1.25 & 1.17 \\
\hline & & & Threonine & 0.92 & 0.70 \\
\hline & & & Tryptophan & 0.28 & 0.30 \\
\hline
\end{tabular}

DCP: dicalcium phosphate, CP: crude protein

*Supplied per kilogram of diet: $13.000 \mathrm{IU}$ vitamin A, $3.500 \mathrm{IU}$ vitamin D3, $100 \mathrm{mg}$ vitamin E, $3 \mathrm{mg}$ vitamin K3, $3 \mathrm{mg}$ vitamin B1, $8 \mathrm{mg}$ vitamin B2, $6 \mathrm{mg}$ vitamin B6, $30 \mathrm{mg}$ vitamin B12, $30 \mathrm{mg}$ niacin, $8 \mathrm{mg}$ calcium-D-pantothenate, $2 \mathrm{mg}$ folic acid, $70 \mathrm{mg}$ vitamin C, $70 \mathrm{mg}$ D-biotin, $200 \mathrm{mg}$ choline chloride, $2 \mathrm{mg}$ canthaxanthin, $0.75 \mathrm{mg}$ apo carotenoic acid ester, 120 mg Mn, 100 mg Zn, 90 mg Fe, 16 mg Cu, 1,5 mg I, 0.75 mg Co, 0.30 mg Se

The live body weight (LBW) (gram) of the chicks were recorded at hatching and then once weekly throughout the study. Overall weekly net feed consumption was calculated by measuring the daily leftover feed. Using this data, average daily live weight gain (ADG) (gram/day/bird), daily feed intake (FI) (gram/day/bird) and feed conversion ratio (FCR) (gram/gram) were calculated.

Experimental chicks were randomly selected on day 112 (feed was removed $8 \mathrm{~h}$ before sampling) after the LBW had been measured. A total of 180 partridges (90 FH and $90 \mathrm{FRH} ; 30$ chicks randomly selected from those with the closest-to-average LBW from each trial group of both management systems; therefore six from each replicate group) were slaughtered.

The data were analyzed using a factorial model of the general linear model procedure in SPSS software (SPSS evaluation version 23.0; IBM Corp., Armonk, NY, USA). The interaction of production system and feed supplementation on live weight, ADG, FI, FCR, slaughter and carcass weights/percentages were determined using the PROC GLM procedure. The model used was:

$$
Y_{i j k}=\mu+P S_{i}+F S_{j}+(P S \times F S)_{i j}+\varepsilon_{i j k}
$$

Where: $Y_{\mathrm{ijk}}$ is the response variable (live weight, ADG, FI, FCR, slaughter and carcass weights/percentages); $\mu$ is the overall mean common to all observation;

$\mathrm{PS}_{\mathrm{i}}$ is the effect of production system (floor housing, free-range housing);

FS is the effect of feed supplementation ( $0 \%, 1 \%, 2 \%)$;

$(\mathrm{PS} \times \mathrm{FS})_{\mathrm{ij}}$ is the interaction of production system and feed supplementation; and $\varepsilon_{\mathrm{ijk}}$ is the residual error.

Statistical significance was set at $P \leq 0.05$. Differences within a significant effect were separated using Duncan's Multiple Range Test. 


\section{Results and Discussion}

The poultry reared under FRH system have access to the outdoors and they can therefore consume grass, insects and worms in addition to their diets. Furthermore, access to the outdoors in this production system may play a role in the increasing the performance of poultry that is not completely domesticated, for example partridges, thereby improving animal welfare and reducing stress (Fanatico et al., 2005; Yamak et al., 2016).

Hatching weights were $14.70 \mathrm{~g}$ and $14.80 \mathrm{~g}, 14.86 \mathrm{~g}$ and $14.70 \mathrm{~g}$, and $14.77 \mathrm{~g}$ and $14.75 \mathrm{~g}$ for the control, trial $1 \%$, and trial $2 \%$ groups in the free-range and cage management systems, respectively. The LBW results for birds fed different levels of yeast autolysate and for the different management systems, are indicated in Table 2. The LBW of the partridges reared in the FH system were, at all time points (except for the $14^{\text {th }}$ day), higher compared to those reared in the FRH system $(P<0.05)$. Dietary supplementation with yeast autolysate increased the LBW when compared to the control group on the $28^{\text {th }}(P<0.002), 42^{\text {nd }}(P$ $<0.000), 84^{\text {th }}(P<0.023), 98^{\text {th }}(P<0.002)$, and $112^{\text {th }}(P<0.000)$ day across both production systems. These results were consistent with the results of a study conducted by Bolacali \& Irak (2017), reporting that adding yeast autolysate to quaildiets increased their live weights. The highest LBWs were determined in the trial $1 \%$ and $2 \%$ groups reared in the $\mathrm{FH}$ system. The interaction between production system and feed supplementation had no effect on LBW at any age.

Table 2 Effects of production system (PS) and yeast autolysate supplementation (FS) on the live body weights $(\mathrm{g})$ of male Alectoris chukar at different time periods

\begin{tabular}{|c|c|c|c|c|c|c|c|c|c|}
\hline Groups & & $14^{\text {th }}$ day & $28^{\text {th }}$ day & $42^{\text {th }}$ day & $56^{\text {th }}$ day & $70^{\text {th }}$ day & $84^{\text {th }}$ day & $98^{\text {th }}$ day & $112^{\text {th }}$ day \\
\hline & Control & 45.64 & 114.15 & 193.89 & 288.68 & 370.60 & 436.14 & 486.99 & 510.71 \\
\hline \multirow[t]{2}{*}{ Free-range } & Trial $1 \%$ & 45.80 & 118.46 & 208.21 & 297.60 & 368.39 & 454.29 & 499.10 & 525.80 \\
\hline & Trial 2\% & 45.18 & 116.35 & 204.10 & 297.05 & 372.91 & 446.20 & 495.77 & 524.00 \\
\hline \multirow[t]{3}{*}{ Floor } & Control & 44.65 & 117.05 & 206.03 & 302.19 & 382.01 & 454.60 & 501.95 & 524.81 \\
\hline & Trial $1 \%$ & 45.93 & 119.32 & 211.73 & 310.78 & 392.39 & 465.64 & 518.77 & 544.15 \\
\hline & Trial 2\% & 46.41 & 120.75 & 210.43 & 301.27 & 397.49 & 471.90 & 519.66 & 541.61 \\
\hline SEM & & 0.44 & 0.93 & 1.97 & 4.58 & 6.57 & 5.59 & 4.08 & 3.12 \\
\hline \multicolumn{10}{|c|}{ Production System (PS) } \\
\hline & Free-range & 45.54 & 116.32 & 202.07 & 294.44 & 370.63 & 445.54 & 493.95 & 520.17 \\
\hline & Floor & 45.66 & 119.04 & 209.40 & 304.74 & 390.63 & 464.04 & 513.46 & 536.85 \\
\hline SEM & & 0.25 & 0.54 & 1.14 & 2.65 & 3.79 & 3.23 & 2.36 & 1.80 \\
\hline \multicolumn{10}{|c|}{ Feed Supplementation (FS) } \\
\hline & Control & 45.14 & $115.60^{\mathrm{b}}$ & $199.96^{\mathrm{b}}$ & 295.43 & 376.31 & $445.37^{b}$ & $494.47^{b}$ & $517.76^{\mathrm{b}}$ \\
\hline & Trial $1 \%$ & 45.87 & $118.89^{\mathrm{a}}$ & $209.97^{a}$ & 304.19 & 380.39 & $459.96^{\mathrm{a}}$ & $508.94^{\mathrm{a}}$ & $534.98^{\mathrm{a}}$ \\
\hline & Trial 2\% & 45.79 & $118.55^{\mathrm{a}}$ & $207.27^{\mathrm{a}}$ & 299.16 & 385.20 & $459.05^{\mathrm{a}}$ & $507.71^{a}$ & $532.80^{\mathrm{a}}$ \\
\hline SEM & & 0.31 & 0.66 & 1.39 & 3.24 & 4.65 & 3.95 & 2.89 & 2.21 \\
\hline \multicolumn{10}{|c|}{ Source of Variation } \\
\hline PS & & $0.729^{\mathrm{ns}}$ & $0.001^{\star *}$ & $0.000^{\star * \star}$ & $0.010^{*}$ & $0.001^{* *}$ & $0.000^{\star * *}$ & $0.000^{\star * *}$ & $0.000^{* \star *}$ \\
\hline FS & & $0.213^{\text {ns }}$ & $0.002^{\star \star}$ & $0.000^{\star * *}$ & $0.176^{\mathrm{ns}}$ & $0.410^{\mathrm{ns}}$ & $0.023^{*}$ & $0.002^{\star \star}$ & $0.000^{\star \star *}$ \\
\hline PS $\times$ FS & & $0.055^{\mathrm{ns}}$ & $0.181^{\mathrm{ns}}$ & $0.100^{\mathrm{ns}}$ & $0.523^{\text {ns }}$ & $0.534^{\mathrm{ns}}$ & $0.448^{\mathrm{ns}}$ & $0.556^{\mathrm{ns}}$ & $0.769^{\text {ns }}$ \\
\hline
\end{tabular}

${ }^{\mathrm{ab}}$ Means in the same column with different superscripts differ significantly $(P<0.05)$ according to the Duncan test

ns Not Significant $(P>0.05),{ }^{*} P<0.05$, ${ }^{* *} P<0.01$, ${ }^{* \star} P<0.001$, SEM: standard error of means.

The growth performances of partridges raised in the different production systems and feed supplementation groups are presented in Table 3. The ADG over the complete study period (4.43 - 4.73 $\mathrm{g} /$ day/bird) was similar to the results reported by Arslan (2004), lower than the results reported by Yamak et al. (2016) and higher than those reported by Khaksar et al. (2014). The interaction between production 
system and feed supplementation had no effect on ADG during the starter, grower, and overall periods. The highest ADG was detected in the trial1\% group in the FH system during the starter and overall periods, and in the trial $2 \%$ group in the $\mathrm{FH}$ system during the grower period. Dietary supplementation with yeast autolysate therefore increased ADG significantly during the grower and overall periods $(P<0.042)$. The best performance was in the trial $2 \%$ group during the grower period $(P<0.046)$, and in the trial $1 \%$ group during the overall period $(P<0.000)$. In terms of production system, the best ADG performance was determined in the chicksreared in the FH systemduring the starter $(P>0.008)$ and overall $(P>0.000)$ periods.

Table 3 Effects of production system (PS) and yeast autolysate supplementation (FS) on the daily live weight gain $(\mathrm{g} /$ day/bird), daily feed intake $(\mathrm{g} /$ day/bird) and feed conversion rate $(\mathrm{g} / \mathrm{g})$ of male Alectoris chukar at different periods (mean)

\begin{tabular}{|c|c|c|c|c|c|c|c|c|c|c|}
\hline \multirow{2}{*}{ Groups } & & \multicolumn{3}{|c|}{ 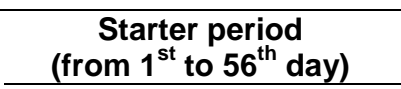 } & \multicolumn{3}{|c|}{$\begin{array}{c}\text { Grower period } \\
\text { (from } 57^{\text {th }} \text { to } 112^{\text {nd }} \text { day) }\end{array}$} & \multicolumn{3}{|c|}{$\begin{array}{c}\text { Overall period } \\
\text { (from } 1^{\text {st }} \text { to } 112^{\text {nd }} \text { day) }\end{array}$} \\
\hline & & ADG & FI & FCR & ADG & FI & FCR & ADG & FI & FCR \\
\hline \multirow{3}{*}{ Free-range } & Control & 4.89 & 24.27 & 4.96 & 4.05 & 39.53 & 9.77 & 4.43 & 31.90 & 7.21 \\
\hline & Trial $1 \%$ & 5.05 & 23.71 & 4.71 & 4.14 & 39.45 & 9.57 & 4.56 & 31.58 & 6.92 \\
\hline & Trial 2\% & 5.04 & 23.72 & 4.71 & 4.16 & 39.36 & 9.47 & 4.55 & 31.54 & 6.94 \\
\hline \multirow[t]{3}{*}{ Floor } & Control & 5.13 & 23.80 & 4.65 & 3.98 & 38.98 & 9.83 & 4.55 & 31.39 & 6.89 \\
\hline & Trial $1 \%$ & 5.29 & 23.54 & 4.46 & 4.17 & 38.72 & 9.30 & 4.73 & 31.13 & 6.58 \\
\hline & Trial 2\% & 5.12 & 23.30 & 4.56 & 4.29 & 38.71 & 9.05 & 4.71 & 31.01 & 6.59 \\
\hline SEM & & 0.08 & 0.11 & 0.07 & 0.08 & 0.24 & 0.19 & 0.03 & 0.11 & 0.05 \\
\hline \multicolumn{11}{|c|}{ Production System (PS) } \\
\hline & Free-range & 4.99 & 23.90 & 4.79 & 4.12 & 39.45 & 9.60 & 4.51 & 31.67 & 7.02 \\
\hline & Floor & 5.18 & 23.55 & 4.55 & 4.15 & 38.80 & 9.39 & 4.66 & 31.18 & 6.69 \\
\hline SEM & & 0.05 & 0.06 & 0.04 & 0.05 & 0.14 & 0.11 & 0.02 & 0.06 & 0.03 \\
\hline \multicolumn{11}{|c|}{ Feed Supplementation (FS) } \\
\hline & Control & 5.01 & $24.04^{\mathrm{a}}$ & $4.80^{\mathrm{a}}$ & $4.01^{b}$ & 39.26 & $9.80^{\mathrm{a}}$ & $4.49^{b}$ & $31.65^{\mathrm{a}}$ & $7.05^{\mathrm{a}}$ \\
\hline & Trial $1 \%$ & 5.17 & $23.62^{b}$ & $4.58^{\mathrm{b}}$ & $4.15^{\mathrm{ab}}$ & 39.08 & $9.43^{\mathrm{ab}}$ & $4.65^{\mathrm{a}}$ & $31.35^{\mathrm{b}}$ & $6.75^{\mathrm{b}}$ \\
\hline & Trial 2\% & 5.08 & $23.51^{b}$ & $4.64^{b}$ & $4.23^{\mathrm{a}}$ & 39.04 & $9.26^{\mathrm{b}}$ & $4.63^{\mathrm{a}}$ & $31.27^{b}$ & $6.77^{\mathrm{b}}$ \\
\hline SEM & & 0.06 & 0.08 & 0.05 & 0.06 & 0.17 & 0.14 & 0.02 & 0.08 & 0.03 \\
\hline \multicolumn{11}{|c|}{ Source of Variation } \\
\hline PS & & $0.008^{\star *}$ & $0.000^{\star \star * *}$ & $0.000^{\star \star \star \star}$ & $0.648^{\text {ns }}$ & $0.003^{\star *}$ & $0.190^{\mathrm{ns}}$ & $0.000^{* \star *}$ & $0.000^{\star \star \star *}$ & $0.000^{\star * *}$ \\
\hline FS & & $0.163^{\text {ns }}$ & $0.000^{* \star *}$ & $0.013^{*}$ & $0.046^{*}$ & $0.637^{\mathrm{ns}}$ & $0.027^{*}$ & $0.000^{\star * \star}$ & $0.006^{* *}$ & $0.000^{* * *}$ \\
\hline$P S \times F S$ & & $0.521^{\mathrm{ns}}$ & $0.361^{\text {ns }}$ & $0.541^{\mathrm{ns}}$ & $0.450^{\text {ns }}$ & $0.929^{\text {ns }}$ & $0.448^{\text {ns }}$ & $0.743^{\text {ns }}$ & $0.939^{\text {ns }}$ & $0.933^{\mathrm{ns}}$ \\
\hline
\end{tabular}

\footnotetext{
${ }^{\mathrm{ab}}$ Means in the same column with different superscripts differ significantly $(P<0.05)$, as indicated by the Duncan test

${ }^{\text {ns }}$ Not Significant $(P>0.05),{ }^{*} P<0.05,{ }^{* *} P<0.01,{ }^{* * *} P<0.001$, SEM: standard error of means, ADG: daily live weight gain, FI: daily feed intake, FCR: feed conversion ratio
}

In this study, the FI during the overall period was $31.01-31.90 \mathrm{~g} /$ day/bird, and this value was determined to be similar to the results reported by Arslan (2004), lower than the results reported by Khaksar et al. (2014) and higher than the results reported by Sengul et al. (2005). The interaction between production system and feed supplementation had no effect on $\mathrm{FI}$ at any time point $(P>0.05)$, but the lowest $\mathrm{FI}$ was determined in the trial $2 \%$ group raised in the $\mathrm{FH}$ system across all periods. It was observed that the $\mathrm{FI}$ was higher in the $\mathrm{FRH}$ system compared to the $\mathrm{FH}$ system $(P<0.001)$, across all periods. Lower feed consumption in the $\mathrm{FH}$ group has been associated with ease of maintaining temperature within the optimal range, due to higher storage densities. However, it is also possible to explain this as being due to the increased movement of partridges in the FRH system due to the decrease in the number of animals per unit area, leading to higher feed consumption in the partridges grown in the FRH system compared to that of the FH system (Esen et al., 2006; Ahammed et al., 2014). 
The FCR during the overall study period was $6.59-7.21 \mathrm{~g} / \mathrm{g}$, similar to the results reported by Arslan (2004), lower than the results reported by Khaksar et al. (2014), and higher than the results reported by Gulsen et al. (2010). The interaction between production system and feed supplementation had no effect on FCR across all periods. The lowest FCR was determined in the trial 1\% group raised in the FH system during the starter and overall periods. During the overall period, the chicks reared in the $\mathrm{FH}$ system had a lower FCR compared to the chicks reared in the FRH system $(P<0.000)$. The improvement in FCR in the FH groups may be associated with the fact that, since there is an area of $592 \mathrm{~cm}^{2} /$ chick in this production system and $2500+7500 \mathrm{~cm}^{2} /$ chick in the FRH system, the metabolic energy requirement in the FRH System is increased and a wider range of motion depending on the low stock density, the feed consumption is also increased when compared with those reared in the FH system (Sarica et al., 2009). Dietary supplementation with yeast autolysate improved the FCR in both the FH and FRH groups across all rearing periods of the study $(P<0.05)$. These results were similar to those found by Khaksar et al. (2014) in their study conducted on partridges.

It was determined that the addition of yeast autolysate exerted a positive effect on growth performance. This positive effect might be related to the effect of the MOS contained in the yeast autolysate, which decrease the reproduction of pathogenic bacteria in the digestive system, promote the health of the digestive system and increase the absorption of the nutrient elements (Mousa et al., 2014; Bolacali \& Irak, 2017). The differences in results between this and previous studies might stem from the partridge species used in the study, the compound and dose of the additives used in the feeds, or the management conditions.

As presented in Tables 4 and 5 , there were no effects of the interaction between production system and yeast autolysate on the weights and percentages of carcass parameters $(P>0.05)$. The slaughter $(P$ $<0.000)$, hot carcass $(P<0.000)$, cold carcass $(P<0.000)$, liver $(P<0.026)$, breast $(P<0.000)$, back $(P$ $<0.005)$, and abdominal fat $(P<0.000)$ weights in the $\mathrm{FH}$ groups were increased compared to those of the

Table 4 Effects of production system (PS) and yeast autolysate FS) supplementation on the slaughter and carcass weights $(\mathrm{g})$ (mean) of the male Alectoris chukar

\begin{tabular}{|c|c|c|c|c|c|c|c|c|c|c|c|c|c|}
\hline $\begin{array}{l}\text { Production } \\
\text { System }\end{array}$ & Feed Additive & Slaughter & $\begin{array}{c}\text { Hot } \\
\text { carcass }^{\#}\end{array}$ & $\begin{array}{c}\text { Cold } \\
\text { carcass }^{\#}\end{array}$ & \# Heart & Liver & Gizzard & Breast & Leg & Wing & Back & Neck & $\begin{array}{c}\text { Abdominal } \\
\text { fat }\end{array}$ \\
\hline \multirow[t]{3}{*}{ Free-range } & Control & 510.71 & 368.05 & 362.66 & 2.59 & 7.65 & 9.77 & 129.89 & 89.84 & 38.86 & 78.36 & 20.94 & 4.79 \\
\hline & Trial 1\% & 525.80 & 388.35 & 383.31 & 2.57 & 8.00 & 10.17 & 140.91 & 95.72 & 39.16 & 81.28 & 21.79 & 4.45 \\
\hline & Trial 2\% & 524.00 & 386.78 & 381.46 & 2.51 & 7.94 & 9.77 & 140.05 & 96.49 & 38.97 & 79.72 & 21.86 & 4.38 \\
\hline \multirow[t]{3}{*}{ Floor } & Control & 524.81 & 385.24 & 375.53 & 2.48 & 7.77 & 8.06 & 139.00 & 90.39 & 37.39 & 81.81 & 21.33 & 5.62 \\
\hline & Trial 1\% & 544.15 & 407.78 & 397.52 & 2.61 & 8.20 & 8.92 & 149.79 & 96.97 & 37.84 & 85.38 & 22.52 & 5.03 \\
\hline & Trial 2\% & 541.61 & 405.74 & 395.57 & 2.50 & 8.13 & 9.01 & 148.71 & 97.06 & 38.24 & 84.43 & 22.25 & 4.89 \\
\hline SEM & & 3.12 & 2.44 & 3.03 & 0.13 & 0.09 & 0.37 & 1.11 & 1.54 & 0.50 & 1.66 & 0.25 & 0.15 \\
\hline \multicolumn{14}{|c|}{ Production System (PS) } \\
\hline & Free-range & 520.17 & 381.06 & 375.81 & 2.56 & 7.86 & 9.90 & 136.95 & 94.01 & 39.00 & 79.78 & 21.53 & 4.54 \\
\hline & Floor & 536.85 & 399.58 & 389.54 & 2.53 & 8.03 & 8.66 & 145.83 & 94.81 & 37.82 & 83.87 & 22.03 & 5.18 \\
\hline SEM & & 1.80 & 1.41 & 1.75 & 0.07 & 0.05 & 0.22 & 0.64 & 0.89 & 0.29 & 0.96 & 0.14 & 0.09 \\
\hline \multicolumn{14}{|c|}{ Feed Supplementation (FS) } \\
\hline & Control & $517.76^{b}$ & $376.64^{\mathrm{b}}$ & $369.10^{b}$ & 2.53 & $7.71^{\mathrm{b}}$ & 8.91 & $134.45^{\mathrm{b}} \mathrm{c}$ & $90.11^{b}$ & 38.12 & 80.08 & $21.13^{b}$ & $5.20^{\mathrm{a}}$ \\
\hline & Trial $1 \%$ & $534.98^{\mathrm{a}}$ & $398.07^{\mathrm{a}}$ & $390.41^{\mathrm{a}}$ & 2.59 & $8.10^{\mathrm{a}}$ & 9.54 & $145.35^{\mathrm{a}} \mathrm{c}$ & $96.34^{\mathrm{a}}$ & 38.50 & 83.33 & $22.15^{\mathrm{a}}$ & $4.74^{\mathrm{b}}$ \\
\hline & Trial 3\% & $532.80^{a}$ & $396.26^{a}$ & $388.52^{\mathrm{a}}$ & 2.51 & $8.04^{a}$ & 9.39 & $144.38^{\mathrm{a}} \mathrm{c}$ & $96.77^{\mathrm{a}}$ & 38.61 & 82.07 & $22.05^{\mathrm{a}}$ & $4.63^{b}$ \\
\hline SEM & & 2.21 & 1.73 & 2.14 & 0.09 & 0.06 & 0.26 & 0.78 & 1.09 & 0.35 & 1.18 & 0.18 & 0.11 \\
\hline \multicolumn{14}{|c|}{ Source of Variation } \\
\hline PS & & $0.000^{\star \star \star}$ & $0.000^{\star \star \star}$ & $0.000^{* * *}$ & $0.779^{\text {ns }}$ & $0.026^{*}$ & $0.000^{\star * *}$ & $0.000^{\star \star \star} 0$ & $0.535^{\text {ns }}$ & $0.007^{* *}$ & ${ }^{*} 0.005^{* *}$ & $0.053^{\text {ns }}$ & $0.000^{\star * \star}$ \\
\hline FS & & $0.000^{\star * *}$ & $0.000^{* * *}$ & $0.000^{* * *} 0$ & $0.806^{\mathrm{ns}}$ & $0.000^{* * *}$ & $0.228^{\mathrm{ns}}$ & $0.000^{\star * *} 0$ & $\begin{array}{c}0.000 * * \\
*\end{array}$ & $0.604^{\mathrm{ns}}$ & $\mathrm{s} 0.162^{\mathrm{ns}} 0$ & $0.000^{\star * \star}$ & $0.002^{* *}$ \\
\hline $\mathrm{PS} \times \mathrm{FS}$ & & $0.769^{\text {ns }}$ & $0.891^{\mathrm{ns}}$ & $0.970^{\text {ns }}$ & $0.823^{\text {ns }}$ & $0.861^{\mathrm{ns}}$ & $0.451^{\text {ns }}$ & $0.979^{\text {ns }} 0$ & $0.968^{\text {ns }}$ & $0.740^{\mathrm{ns}}$ & s $0.931^{\text {ns }}$ & $0.732^{\text {ns }}$ & $0.530^{\mathrm{ns}}$ \\
\hline
\end{tabular}


Table 5 Effects of production system (PS) and yeast autolysate supplementation (FS) on the slaughter and carcass percentages (mean) of the male Alectoris chukar (\%)

\begin{tabular}{|c|c|c|c|c|c|c|c|c|c|c|c|c|}
\hline $\begin{array}{l}\text { Production } \\
\text { System }\end{array}$ & $\begin{array}{l}\text { Feed } \\
\text { Additive }\end{array}$ & $\begin{array}{c}\text { Hot } \\
\text { carcass }\end{array}$ & $\begin{array}{c}\text { Cold } \\
\text { carcass }\end{array}$ & Heart $^{1}$ & Liver $^{1}$ & Gizzard $^{1}$ & ${ }^{1}$ Breast $^{2}$ & Leg $^{2}$ & Wing $^{2}$ & Back $^{2}$ & $\mathrm{Neck}^{2}$ & $\begin{array}{c}\text { Abdominal } \\
\text { fat }^{2}\end{array}$ \\
\hline \multirow[t]{3}{*}{ Free-range } & Control & 72.07 & 71.01 & 0.51 & 1.50 & 1.91 & 35.82 & 24.77 & 10.72 & 21.61 & 5.77 & 1.32 \\
\hline & Trial 1\% & 73.87 & 72.89 & 0.49 & 1.52 & 1.94 & 36.76 & 24.98 & 10.22 & 21.20 & 5.68 & 1.16 \\
\hline & Trial 2\% & 73.81 & 72.80 & 0.48 & 1.52 & 1.86 & 36.72 & 25.31 & 10.22 & 20.89 & 5.73 & 1.15 \\
\hline \multirow[t]{4}{*}{ Floor } & Control & 73.41 & 71.56 & 0.47 & 1.48 & 1.53 & 37.02 & 24.07 & 9.96 & 21.78 & 5.68 & 1.50 \\
\hline & Trial $1 \%$ & 74.94 & 73.05 & 0.48 & 1.51 & 1.64 & 37.68 & 24.40 & 9.52 & 21.48 & 5.67 & 1.27 \\
\hline & Trial 2\% & 74.91 & 73.04 & 0.46 & 1.50 & 1.66 & 37.59 & 24.54 & 9.67 & 21.34 & 5.62 & 1.24 \\
\hline & SEM & 0.23 & 0.29 & 0.02 & 0.01 & 0.07 & 0.09 & 0.39 & 0.09 & 0.37 & 0.05 & 0.04 \\
\hline \multicolumn{13}{|c|}{ Production System (PS) } \\
\hline & Free-range & 73.25 & 72.23 & 0.49 & 1.51 & 1.90 & 36.43 & 25.02 & 10.38 & 21.23 & 5.73 & 1.21 \\
\hline & Floor & 74.42 & 72.55 & 0.47 & 1.50 & 1.61 & 37.43 & 24.33 & 9.71 & 21.54 & 5.66 & 1.33 \\
\hline & SEM & 0.13 & 0.17 & 0.01 & 0.01 & 0.04 & 0.05 & 0.23 & 0.05 & 0.22 & 0.03 & 0.02 \\
\hline \multicolumn{13}{|c|}{ Feed Supplementation (FS) } \\
\hline & Control & $72.74^{\mathrm{b}}$ & $71.28^{\mathrm{b}}$ & 0.49 & 1.49 & 1.72 & $36.42^{b}$ & 24.42 & $10.34^{\mathrm{a}}$ & 21.70 & 5.73 & $1.41^{\mathrm{a}}$ \\
\hline & Trial $1 \%$ & $74.40^{\mathrm{a}}$ & $72.97^{\mathrm{a}}$ & 0.48 & 1.51 & 1.79 & $37.22^{\mathrm{a}}$ & 24.69 & $9.87^{b}$ & 21.34 & 5.67 & $1.21^{\mathrm{b}}$ \\
\hline & Trial $2 \%$ & $74.36^{\mathrm{a}}$ & $72.92^{\mathrm{a}}$ & 0.47 & 1.51 & 1.76 & $37.15^{\mathrm{a}}$ & 24.92 & $9.94^{b}$ & 21.12 & 5.68 & $1.19^{b}$ \\
\hline & SEM & 0.16 & 0.21 & 0.02 & 0.01 & 0.05 & 0.06 & 0.28 & 0.06 & 0.26 & 0.03 & 0.03 \\
\hline \multicolumn{13}{|c|}{ Source of Variation } \\
\hline PS & & $0.000^{\star * *}$ & $0.198^{\text {ns }}$ & $0.265^{\mathrm{ns}}$ & $0.199^{\text {ns }}$ & $0.000^{\star * *}$ & $0.000^{\star * *}$ & $0.040^{*}$ & $0.000^{* * *}$ & $0.328^{\text {ns }}$ & $0.069^{\text {ns }}$ & $0.000^{* \star *}$ \\
\hline FS & & $0.000^{\star * *}$ & $0.000^{* * *}$ & $0.715^{\mathrm{ns}}$ & $0.214^{\text {ns }}$ & $0.644^{\mathrm{ns}}$ & $0.000^{* * *}$ & $0.447^{\mathrm{ns}}$ & $0.000^{* * *}$ & $0.310^{\text {ns }} \mathrm{C}$ & $0.449^{\text {ns }}$ & $0.000^{* * *}$ \\
\hline$P S \times F S$ & & $0.812^{\mathrm{ns}}$ & $0.783^{\text {ns }}$ & $0.856^{\text {ns }}$ & $0.985^{\text {ns }}$ & $0.424^{\mathrm{ns}}$ & $0.156^{\text {ns }}$ & $0.971^{\mathrm{ns}}$ & $0.484^{\text {ns }}$ & $0.932^{\text {ns }} C$ & $0.607^{\text {ns }}$ & $0.471^{\mathrm{ns}}$ \\
\hline
\end{tabular}

FRH groups. On the other hand, the gizzard $(P<0.000)$ and wing $(P<0.007)$ weights of the partridges reared in the FRH system were higher compared to those of the partridges reared in the FH system.

This situation might be associated with the fact that the gizzards of the partridges reared in the FRH system were more developed compared to those of the partridges reared in the FH system, due to their scratching and pecking behaviour and their flying abilities may have been more developed, due to the decrease in stocking density. It was determined that the effects of production system on the carcass parameters (except for the weights of the liver and wings) were in accordance with the results reported by Yamak et al. (2016).

When the results were analyzed in terms of the dietary supplementation with yeast autolysate, the trial $1 \%$ and trial $2 \%$ groups had higher slaughter, hot carcass, cold carcass, liver, breast, leg, and neck weights $(P<0.000)$ compared to those of the control group, but abdominal fat weights were lower $(P<0.002)$. The improved carcass parameters following the addition of yeast autolysate to diets might be associated with the fact that MOS, which is one of the components of the yeast autolysate, increases the heights of the villi in the intestines, as well as the digestibility of proteins (Spring, 1996; Yang et al., 2007).

The average carcass yield in partridges is $72 \%$, varying between $68 \%$ and $77 \%$ (Kokoszyński et al., 2013; Khaksar et al., 2014; Wnuk et al., 2014; Yamak et al., 2016). In the present study, the carcass yield was from $71.01 \%$ to $73.05 \%$, breast percentages were from $35.82 \%$ to $37.68 \%$, and leg percentages were from $24.07 \%$ to $25.31 \%$ (Table 5). The carcass yield in the present study was similar to the results of Gulsen et al. (2010), lower than the results of Yamak et al. (2016) and higher than the results of Cetin (2000). The breast percentages found in the present study were similar to the results of Yamak et al. (2016), but higher than the results of Gulsen et al. (2010). The leg percentages were similar to the results of Yamak et al. 
(2016), lower than the results of Khaksar et al. (2014), but higher than those of Wnuk et al. (2014). Thus, in terms of carcass yield, breast and leg percentages, the results of this study are within the range of literature estimates.

Poultry housed in FRH systems are more physically active and exhibit more natural behavior compared to poultry housed in FH systems (Nielsen et al., 2003; Leyendecker et al., 2005; SosnowkaCzajka et al., 2006). In the present study, the gizzard $(P<0.000)$ and leg percentages $(P<0.04)$ in the $\mathrm{FRH}$ groups were elevated compared to those in the FR groups. This situation might stem from the fact that partridges reared in $\mathrm{FRH}$ are more active than those reared in $\mathrm{FH}$, in terms of flying and litter-pecking. The fact that the gizzard percentages in FRH groups were highermay have been due to scratching, litter-pecking, and walking, which lead to more development of these muscles (Esen et al., 2006). The hot carcass, breast, and abdominal fat percentages in partridges in the $\mathrm{FH}$ groups were higher than those in the $\mathrm{FRH}$ system $(P$ $<0.000)$. These results were in accordance with those reported by Yamak et al. (2016). The lowest abdominal fat percentages were observed in partridges reared in the $\mathrm{FRH}$ system in the trial $2 \%$ group. The FRH system reduced the abdominal fat percentages in the partridges $(P<0.000)$. The current finding was similar to the outcomes of research that indicated a significant impact of housing system on the relative abdominal fat weight and reported lower weights with free-range systems (Dou et al., 2009; Pavlovski et al., 2009; Wang et al., 2009).

In this study, the hot and cold carcass yields and breast percentages in the trial $1 \%$ group were higher than those of the other groups $(P<0.000)$. Furthermore, the addition of yeast autolysate to the diet reduced abdominal fat percentage in a dose-dependent manner. Similar results, reported by Bolacali and Irak (2017), determined that the addition of yeast autolysate reduced the abdominal fat ratio in quail. Meanwhile, Falaki et al. (2011) reported that MOS addition had no effect on the percentage of abdominal fat in broiler chicks.

\section{Conclusions}

Production systems did not have any significant effect on the carcass yield of partridges. Partridges reared in the $\mathrm{FH}$ system exhibited improved growth performance compared to those rearedin the $\mathrm{FRH}$ system; however, partridges reared in $\mathrm{FRH}$ had higher wing percentages and lower abdominal fat percentages compared to those reared in the $\mathrm{FH}$ system. The best growth performance, carcass yield, breast, and leg percentages were observed in partridges receiving $1 \%$ yeast autolysate in their diet. When considering the fact that partridges are gamebirds, that housing poultry in cage production systems has been prohibited in recent years and that there are positive effects associated with using yeast autolysate as a prebiotic, it is therefore recommended that a free-range production system is being used for partridge breeding with the addition of $1 \%$ yeast autolysate to the diet of the birds.

\section{Acknowledgments}

The authors give special thanks to R.A.Cihat Ozturk for his assistance in the research process, and the Spandidos Publications UK, Ltd. Language Editing Service for assistance with the English language and grammar in this manuscript.

\section{Authors' Contributions}

MB was in charge of organizing and supervising the course of the project and the article. MB, MK and LA took responsibility for the logical interpretation and presentation of the results. MB and TT wrote the manuscript.

\section{Conflict of Interest Declaration}

The authors declare no conflict of interest.

\section{References}

Ahammed, M., Chae, B.J., Lohakare, J., Keohavong, B., Lee, M.H., Lee, S.J., Kim, D.M., Lee1, J. Y.\& Ohh, S.J., 2014. Comparison of aviary, barn and conventional cage raising of chickens on laying performance and egg quality. Asian Australas. J. Anim. Sci. 27, 1196-1203.

Arslan, C., 2004. Effect of dietary probiotic supplementation on growth performance in the rock partridge (Alectoris graeca). Turk J Vet Anim Sci. 28, 887-891.

AOAC, 2000. Official methods of analysis (17th ed.). Association of Official Analytical Chemists, Inc., Arlington, Virginia, USA.

Aydin, D. \& Aydin, R., 2012. The effects of dietary yeast extract containing mannan oligosaccharide and $\beta$-glucans on body performance, feed efficiency and carcass characteristics in Japanese quail. J. Anim. Sci. Adv. 2, 184-187.

Bolacali, M. \& Irak, K., 2017. Effect of dietary yeast autolysate on performance, slaughter, and carcass characteristics, as well as blood parameters, in quail of both genders. S. Afr. J. Anim. Sci. 47, 460-470.

Bonos, E.M., Christaki, E.V. \& Florou-Paneri, P.C., 2010. Performance and carcass characteristics of Japanese quail as affected by sex or mannan oligosaccharides and calcium propionate. S. Afr. J. Anim. Sci. 40, 173-184.

Castanon, J.I.R., 2007. History of the use of antibiotic as growth promoters in European poultry feeds. Poult Sci. 86, 2466-2471. 
Cetin, O., 2000. Fattening performance and carcass characteristics of Rock Partridges ( $A$. Graeca) at different killing ages. J. Poult. Res. 2, 41-44.

Cetin, O. \& Kirikci K., 2000. Alternative Poultry Raising. Pheasant-Chukar. Selcuk Univ. Found. Press, Konya, Turkey.

Dou, T.C., Shi, S.R., Sun, H.J.\& Wang, K.H., 2009. Growth rate, carcass traits and meat quality of slow-growing chicken grown according to three raising systems. Anim. Sci. Pap. Rep. 27, 361-369.

Esen, F., Ozdemir, G. \& Ozbey, O., 2006. The effect of cage stocking density on growth, slaughtering and carcass characteristics of rock partridges (A. graeca). Int. J. Poult. Sci. 5, 04-08.

Falaki, M., Shargh, M.S., Dastar, B. \& Zerehdaran, S., 2011. Effect of different levels of probiotic and prebiotic on performance and carcass characteristics of broiler chickens. J. Anim. Vet. Adv.10, 378-384.

Fanatico, A.C., Pillai, P.B., Cavitt, L.C., Owens, C.M. \& Emmert, J.L., 2005. Evaluation of slower-growing broiler genotypes grown with and without outdoor access: growth performance and carcass yield. Poult Sci. 84, 13211327.

Gulsen, N., Umucalilar, H.D., Kirikci, K., Hayirli, A., Aktumsek, A. \& Alasahan, S., 2010. Sunflower oil supplementation alters meat quality but not performance of growing partridges (Alectoris chukar). J. Anim. Physiol. Anim. Nutr. 94, 196-203.

Khaksar, V., Veldkamp, T. \& Hashemipour, H., 2014. Effect of a prebiotic on performance of partridge. J. Anim. Physiol. Anim. Nutr. 98, 511-516.

Kokoszyński, D., Bernacki, Z., Korytkowska, H., Wilkanowska, A. \& Frieske, A., 2013. Carcass composition and meat quality of Grey Partridge (Perdix perdix L.). Journal of Central European Agriculture 14, 378-287.

Leyendecker, M., Hamann, H., Hartung, J., Kamphues, J., Neumann, U., Surie, C. \& Distl, O., 2005. Keeping laying hens in furnished cages and an aviary housing system enhances their bone stability. Br. Poult. Sci. 46, 536-544.

Mousa, S.M.M., Soliman, M.M. \& Bahakaim, A.S.A., 2014. Effect of Mannan Oligosaccharides and $\beta$-glucans on productive performance and some physiological and immunological parameters of growing Japanese quail chicks. Egyptian Poult. Sci. J. 34, 433-451.

Nielsen, B.L., Thomsen, M.G., Sorensen, J P. \& Young, J.F., 2003. Feed and strain effects on the use of outdoor areas by broilers. Br. Poult. Sci. 44, 161-169

Nikpiran, H., Vahdatpour, T., Babazadeh, D. \& Vahdatpour, S., 2013. Effects of Saccharomyces Cerevisiae, Thepax and their combination on blood enzymes and performance of Japanese quails (Coturnix Japonica). J. Anim. Plant Sci. 23, 369-375.

Patterson, J.A. \& Burkholder, K.M., 2003. Application of prebiotics and probiotics in poultry production. Poult. Sci. 82, 627-631.

Pavlovski, Z., Škrbić, Z., Lukić, M., Petričević, V. \& Trenkovski, S., 2009. The effect of genotype and housing system on production results of fattening chickens. Biotechnol. Anim. Res. 25, 221-229.

Sarica, M., Ocak, N., Karacay, N., Yamak, U., Kop, C. \& Altop, A., 2009. Growth, slaughter and gastrointestinal tract traits of three turkey genotypes under barn and freerange housing systems. Br. Poult. Sci. 50, 487-494.

Sengul, T., Cetin M., Ozmen, G. \& Dede, E., 2005. Comparison of Growth Performances of Chukar Partridges (A. chukar) in Different Housing Systems. J. Poult. Res. 6, 53-56.

Simsek, U.G., Yilmaz, O., Gokce, Z.,Ciftci, M. \& Erisir, Z., 2017. The effect of housing systems on fatty acid structures of liver, abdominal fat and breast muscle in broiler production. Indian J. Anim. Sci. 87, 919-923.

Sosnowka-Czajka, E., Herbut, I.S.E. \& Muchacka, R., 2006. Free-range and barn management systems as related to productivity and welfare of broiler chickens from different commercial lines. XII European Conference, Verona, Italy, World's Poult Sci Jl, Book of abstracts. Vol. 62. P.605-610

Spring, P., 1996. Effects of mannan oligosaccharide on different cecal parameters and on cecal concentrations of enteric pathogens in poultry. Thesis (DSc). Swiss Federal Institute of Technology Zurich, Zurich, Switzerland.

Wang, K.H., Shi, S.R., Dou, T.C. \& Sun, H.J., 2009. Effect of a free-range raising system on growth performance, carcass yield, and meat quality of slow-growing chicken. Poult. Sci. 88, 2219-2223.

Wnuk, A., Łukasiewicz, M., Mroczek-Sosnowska, N., Niemiec, J., Popczyk, B. \& Balcerak, M., 2014. Effect of sex on results of slaughter analysis of grey partridge Perdix perdix. SGGW, Anim. Sci. 53, 67-72.

Yamak, U.S., Sarica, M., Boz, M.A. \& Ucar, A.,2016. The effect of production system (barn and free-range), slaughtering age and gender on carcass traits and meat quality of partridges (Alectoris chukar). Br. Poult. Sci. 57, 185-192.

Yang, Y., lji, P.A. \& Choct, M., 2007. Effects of different dietary levels of mannanoligosaccharide on growth performance and gut development of broiler chickens. Asian-Aust. J. Anim. Sci. 20, 1084-1091.

Yenilmez, F. \& Uruk E., 2016. Free Range System, Advantages and Disadvantages. Nevşehir J. Sci. Tech. 5, 315-324.

Yolcu, H.I., Aslan, A., Serttas, A., Saribasak, H., Uysal, H. \&Cobanoglu A., 2013. Monitoring the released patridges to the natural habitat and determining their survival and regeneration rates (The Study Case in Elmali Cedar Forest), Directorate of Western Mediterranean Forestry Research Institute, Project Final Report No. 19.8405/2011-2014.

Yilmaz, A.\& Tepeli, C., 2009. The native partridges of Turkey. Int. J. Galliformes Conserv. 1, 9-11. 